\title{
Less is More: Treatment with BTH and Laminarin Reduces Herbivore-Induced Volatile Emissions in Maize but Increases Parasitoid Attraction
}

\author{
Islam S. Sobhy • Matthias Erb • Awad A. Sarhan • \\ Monir M. El-Husseini • Nasser S. Mandour • \\ Ted C. J. Turlings
}

Received: 28 October 2011 /Revised: 8 March 2012 / Accepted: 9 March 2012 / Published online: 29 March 2012

(C) Springer Science+Business Media, LLC 2012

\begin{abstract}
Chemical plant strengtheners find increasing use in agriculture to enhance resistance against pathogens. In an earlier study, it was found that treatment with one such resistance elicitor, BTH (benzo-(1, 2, 3)-thiadiazole-7-carbothioic acid $S$-methyl ester), increases the attractiveness of maize plants to a parasitic wasp. This surprising additional benefit of treating plants with BTH prompted us to conduct a series of olfactometer tests to find out if BTH and another commercially available plant strengthener, Laminarin, increase the attractiveness of maize to three important parasitic wasps, Cotesia marginventris, Campoletis sonorensis, and Microplitis rufiventris. In each case, plants that were sprayed with the plant strengtheners and subsequently induced to release volatiles by real or mimicked attack by Spodoptera littoralis caterpillars became more attractive to
\end{abstract}

I. S. Sobhy $\cdot$ T. C. J. Turlings $(\bowtie)$

FARCE Lab., Institute of Biology, Faculty of Sciences,

Neuchâtel University,

Rue Emil-Argand 11,

2009 Neuchâtel, Switzerland

e-mail: ted.turlings@unine.ch

M. Erb

Root-Herbivore Interactions Group,

Max Planck Institute for Chemical Ecology,

Jena 07745 , Germany

I. S. Sobhy $\cdot$ A. A. Sarhan $\cdot$ N. S. Mandour

Department of Plant Protection,

Public Service Center of Biological Control (PSCBC),

Faculty of Agriculture, Suez Canal University,

41522 Ismailia, Egypt

M. M. El-Husseini

Department of Economic Entomology and Pesticides,

Faculty of Agriculture, Cairo University,

298 Giza, Egypt the parasitoids than water treated plants. The elicitors alone or in combination with plants that were not induced by herbivory were not attractive to the wasps. Interestingly, plants treated with the plant strengtheners did not show any consistent increase in volatile emissions. On the contrary, treated plants released less herbivore-induced volatiles, most notably indole, which has been reported to interfere with parasitoid attraction. The emission of the sesquiterpenes (E)- $\beta$-caryophyllene, $\beta$-bergamotene, and (E)- $\beta$-farnesene was similarly reduced by the treatment. Expression profiles of marker genes showed that BTH and Laminarin induced several pathogenesis related (PR) genes. The results support the notion that, as yet undetectable and unidentified compounds, are of major importance for parasitoid attraction, and that these attractants may be masked by some of the major compounds in the volatile blends. This study confirms that elicitors of pathogen resistance are compatible with the biological control of insect pests and may even help to improve it.

Keywords Herbivore-Induced Plant Volatiles (HIPVs) . Parasitoid attraction · Plant enhancers · Defense gene expression $\cdot$ Indole $\cdot$ Sesquiterpene

\section{Introduction}

Upon herbivore attack, plants emit specific blends of volatiles that attract natural enemies of the herbivores (Turlings and Wäckers, 2004; Arimura et al., 2009; Dicke and Baldwin, 2010). This phenomenon has led to the idea that by enhancing these volatile signals in crop plants, biological control of insect pests may be improved (Degenhardt et al., 2003; Turlings and Ton, 2006). Recent attempts to 
genetically manipulate the emission of volatile compounds that are involved in the attraction of natural enemies have been successful (Kappers et al., 2005; Schnee et al., 2006), and a first demonstration that this approach can indeed help to enhance crop protection in the field has been shown with transgenic plants that emit $(E)-\beta$-caryophyllene from their roots and thereby attract entomophagous nematodes, which in turn reduce the abundance of root feeding herbivores (Degenhardt et al., 2009). However, for leaf-feeding pests, the transgenic approach appears to be more complicated, because herbivore induced leaf-volatile blends are more complex, making it difficult to pinpoint the key compounds that are involved in the attraction of predators and parasitoids (D'Alessandro et al., 2006; Dicke, 2009).

An alternative strategy that circumvents this problem is to use elicitors that induce general plant defense responses, including volatile signals (D'Alessandro et al., 2009). The two main plant hormones that could be targeted by such an approach are salicylic acid (SA) and jasmonic acid (JA). Biotrophic pathogens and piercing/sucking insects commonly trigger SA-mediated defenses, whereas necrotrophic pathogens and chewing herbivores induce the JA pathway (Heil and Bostock, 2002; Thaler et al., 2002a; Arimura et al., 2005; Smith et al., 2009). Hence, treatment with these hormones or their analogues may induce resistance against pathogens and insects, respectively (Arimura et al., 2005; Bostock, 2005). Jasmonic acid is also implicated in indirect defense responses, such as the production of extrafloral nectar (Heil, 2004) and the emission of volatile blends that are implicated in the attraction of parasitoids and predators (Turlings et al., 1990; Dicke et al., 1999). Indeed, it has been shown that JA treatment can increase the parasitism of caterpillars in tomato (Thaler, 1999), suggesting that elicitors targeting this pathway could be applied to enhance the attractiveness of crop plants to biological control agents. So far, however, only elicitors of pathogen resistance are commercially used as "plant enhancers" (Gorlach et al., 1996).

Several studies suggest that there is negative cross talk between the SA pathway and the JA pathway, and the induction of pathogen resistance may, therefore, lead to increased susceptibility to insect herbivores (Heil and Bostock, 2002; Thaler et al., 2002b) and perhaps attenuation of volatile emissions. To test the latter, Rostás and Turlings (2008) conducted a series of olfactometer experiments with maize plants that were treated with the plant enhancer BTH (benzo-(1, 2, 3)-thiadiazole-7-carbothioic acid $S$-methyl ester). BTH is a chemical mimic of SA that triggers the expression of a high number of defense genes against microbes (Morris et al., 1998; von Rad et al., 2005), and it has been used successfully to induce resistance to a wide range of diseases on field crops (Friedrich et al., 1996; Inbar et al., 1998; Tally et al., 1999). Against expectations, Rostás and Turlings (2008) found that Microplitis rufiventris, a larval endoparasitoid wasp of numerous lepidopteran caterpillars, was much more attracted to BTH-treated plants than to non-treated plants. Compared to non-treated plants, BTHtreated plants released lower amounts of certain volatiles, in particular the aromatic compound indole (Rostás and Turlings, 2008). In another study, it was shown that inhibiting the production of indole indeed enhances the attraction of M. rufiventris (D'Alessandro et al., 2006), but other, yet unknown changes induced by BTH treatment may also have contributed to the dramatic increase in attractiveness that was observed by Rostás and Turlings (2008).

The current study was conducted to test whether BTH and another plant enhancer, Laminarin, have a general positive effect on the attractiveness of plants to parasitoids. Laminarin is a water-soluble $\beta-1$, 3glucan with an average degree of polymerization of 25 glucose units (Read et al., 1996), and it has been shown to stimulate defense responses in cell suspensions of tobacco (Klarzynski et al., 2000) and grapevine (Aziz et al., 2003; Trouvelot et al., 2008). It induces the accumulation of phytoalexins and expression of a set of pathogenesis related (PR) proteins (Klarzynski et al., 2000; Aziz et al., 2003) through the activation of the SA pathway (Ménard et al., 2004). As both BTH and Laminarin can stimulate the SA pathway, we speculated that they may have the same positive effect on parasitoid attraction. To test this notion, we conducted a series of olfactometer experiments with three generalist parasitoids that attack lepidopteran herbivores, including several Spodoptera species. We tested the responses of the endoparasitoids Microplitis rufiventris (Kok.), Cotesia marginiventris (Cresson) [Hymenoptera: Braconidae], and Campoletis sonorensis (Cameron) [Hymenoptera: Ichneumonidae] to odors of maize seedlings that were either attacked by larvae of Spodoptera littoralis (Bios.) [Lepidoptera: Noctuidae] or induced by mechanical damage and treatment with regurgitant of the same herbivore. Both these treatments strongly induce the emission of parasitoid attractants (Turlings et al., 1990, 1998; Alborn et al., 1997). Each of the three parasitoid species is known to be attracted to the odor of hostinfested maize plants, but they show distinct differences in their odor preferences and response patterns (Hoballah and Turlings, 2005; Tamò et al., 2006; Erb et al., 2010). We, therefore, hypothesized that treatments with BTH or Laminarin may have different effects on the different parasitoids. To correlate parasitoid attraction with the induction of defenses and the emission of plant volatiles, we also measured the expression of a set of defense marker genes, in addition to collecting and analyzing the volatile emissions of treated plants. As BTH and Laminarin are increasingly used as plant strengtheners in agriculture (Vallad and Goodman, 2004), the results of this study will help to estimate their potential impact on biological control of pest insects by parasitoids. 


\section{Methods and Materials}

Maize Plants Zea mays var. Delprim plants were grown in plastic pots (11 cm high, $4 \mathrm{~cm}$ diam) in commercial potting soil (Ricoter, Aussaaterde, Aarberg, Switzerland) and grown in a climate chamber (CLF plant climatics, Percival) at $25 \pm$ $2^{\circ} \mathrm{C}, 60 \pm 5 \%$ r.h., $16: 8 \mathrm{hL}: \mathrm{D}$, and $926 \mu \mathrm{mol} / \mathrm{m}^{2} \mathrm{~s}^{1}$. Maize plants used for the experiments were 10-14 d-old and had three fully developed leaves.

Herbivores Eggs of Spodoptera littoralis Boisd. (Lepidoptera: Noctuidae) were supplied by Syngenta ${ }^{\mathrm{TM}}$ (Stein, Switzerland). Newly hatched larvae were reared in transparent plastic boxes on a wheat germ-based artificial diet until they had reached the second instar, at which point they were used in the experiments (Turlings et al., 2004).

Parasitoids A colony of the solitary larval endoparasitoids $M$. rufiventris was reared in the laboratory as follows. Twenty-five $S$. littoralis caterpillars (3-4 d-old) were offered to a single mated female (4-7 d-old) for $3 \mathrm{~h}$ in a plastic box ( $5 \mathrm{~cm}$ high, $9.5 \mathrm{~cm}$ diam). The parasitized caterpillars were kept in an incubator $\left(25^{\circ} \mathrm{C}, 16: 8 \mathrm{hL}: \mathrm{D}\right)$ until the parasitoids formed cocoons. Emerging adults were sexed and kept in plastic cages $(30 \times 30 \times 30 \mathrm{~cm}$, Bugdorm I, MegaView Ltd, Taiwan) in incubators $\left(25 \pm 2^{\circ} \mathrm{C}, 40 \pm 10 \%\right.$ r.h., 16:8 hL:D). Cages were supplied with moist cotton wool and droplets of honey.

To rear C. marginiventris and C. sonorensis, about $45 S$. littoralis larvae were offered to three mated females in a plastic box (described above). Wasps were allowed to oviposit for $24 \mathrm{~h}$ and were then removed. Herbivore larvae were kept on artificial diet in the boxes until the emergence of the wasp cocoons. Cocoons were removed from the herbivore boxes and transferred to rearing cages. Cages were checked daily for eclosed individuals. Adult parasitoids were provided with water and honey. Cages with adults were transferred to the laboratory $30 \mathrm{~min}$ before the bioassays to be acclimatized to the ambient laboratory conditions.

Plant Strengtheners BTH (BION $\left.{ }^{\mathrm{TM}}\right)$ was obtained from Syngenta, Switzerland, as a water-dispersible granular formulation containing $50 \%$ active ingredient. Laminarin (IODUS $40^{\circledR}$ ) was obtained from Stähler, Switzerland, as a soluble liquid (SL) formulation containing 3.5\% active ingredient. Both BTH and Laminarin were sprayed on 9-11 d-old plants $48 \mathrm{~h}$ before the experiment (Rostás and Turlings, 2008) at concentrations of $0.15 \mathrm{~g} / \mathrm{L}(\mathrm{BTH})$ and $20 \mathrm{ml} / \mathrm{L}$ (Laminarin). These concentrations correspond to the recommended doses by the manufacturers for application in agriculture.

Olfactometer Bioassays A series of experiments that used a six-arm-olfactometer was conducted to evaluate whether the application of the two plant enhancers to maize plants had an effect on the attractiveness of maize plants to parasitic wasps. In all experiments, 2-6 d-old mated female wasps were used (Tamò et al., 2006). The parasitoids were naïve, which means that as adults had no prior contact with host insects or maize plants. For the choice assays, six female wasps were removed from their cage with an aspirator and released into the central choice chamber of the olfactometer (Turlings et al., 2004). Attracted by the diffuse light coming from above, the wasps moved up to the top of the chamber. Depending on the attractiveness of the different odor sources, they then walked into one of the six arms connected to the central chamber. The central choice chamber was connected via a Tygon tube to a water-filled glass U-tube that served as a pressure gauge to balance incoming and outgoing air, thus minimizing pressure differences with the outside (Turlings et al., 2004; Rasmann and Turlings, 2007). Each group of wasps was given $30 \mathrm{~min}$ to make a choice. Wasps that did not enter an arm after this time were removed from the central part of the olfactometer and considered as individuals that made "no choice" (D'Alessandro et al., 2009). Five groups of six wasps were tested on each experimental day. Each olfactometer experiment was repeated 6 times on different days, each time with a new set of sprayed plants as odor sources and with new wasps. The position of the odor source was changed clock-wise after each day of testing to avoid position effects. All bioassays were carried out between 9:00 A.M. and 5:00 P.M.

\section{Odor Sources}

Spodoptera littoralis Damaged Maize Plants Two days before the olfactometer experiments, plants were subjected to three treatments: The seedlings were sprayed either with BTH $(0.15 \mathrm{~g} / \mathrm{L})$, Laminarin $(20 \mathrm{ml} / \mathrm{L})$, or distilled water using a spray bottle. The different solutions were distributed equally over the different leaves. To induce maize plants to emit plant volatiles, 10 second instars of S. Littoralis larvae were added to each plant. Plants were infested $24 \mathrm{~h}$ after elicitor treatment, on the evening before an experimental day. After infestation, plants were kept under laboratory conditions $\left(25 \pm 2{ }^{\circ} \mathrm{C}, 16: 8 \mathrm{hL}: \mathrm{D}\right)$. The following odor sources then were offered to the parasitoids: (i) a maize plant treated with BTH and damaged by caterpillars; (ii) a maize plant treated with Laminarin and damaged by caterpillars; and (iii) a maize plant treated with distilled water and damaged by caterpillars. The remaining three vessels were left empty. In the olfactometer setup, these empty vessels were alternated with vessels that contained a plant.

Mechanically Damaged Maize Plants The purpose of this experiment was to rule out confounding effects of the plant enhancers on the herbivores that may influence volatile emission. First, plants were sprayed with BTH, Laminarin, 
or water as described above. Second, to mimic leafherbivore attack, the abaxial side of all fully developed leaves $\left(20 \mathrm{~mm}^{2}\right)$ was scratched with a scalpel blade without damaging the midrib, and $10 \mu \mathrm{l}$ of S. littoralis larval regurgitant were applied to each wound with a micropipette. Regurgitant had been collected previously with a micropipette from 4th instars that had been feeding on maize leaves for at least $24 \mathrm{~h}$, and was stored at $-80^{\circ} \mathrm{C}$ until use (Turlings et al., 1998). The above mentioned procedure was carried out the evening before and a second time on the morning of each experimental day, about $3 \mathrm{~h}$ before the start of the bioassays. The offered odor sources in this experiment were: (i) a maize plant treated with BTH and induced by mechanical damage and regurgitant; (ii) a maize plant treated with Laminarin and induced by mechanical damage and regurgitant; and (iii) a maize plant treated with distilled water and induced by mechanical damage and regurgitant. The three other vessels remained empty and were alternated with the treatment vessels.

Undamaged Maize Plants To test whether BTH and Laminarin change the attractiveness of maize plants in the absence of herbivory, parasitoids were offered a choice between three undamaged maize plants. Plants were treated with plant enhancers as described above and left for $48 \mathrm{~h}$. The offered odor sources consisted of: (i) undamaged maize plant treated with BTH; (ii) undamaged maize plant treated with Laminarin; and (iii) undamaged maize plant treated with distilled water. Again, these the treatment vessels were alternated with three empty vessels.

Plant Enhancers To complete the dataset, we also tested whether the odor of BTH and Laminarin directly affected the behavior of the studied wasps. For this purpose, filter papers (595 Rundfilter $185 \mathrm{~mm}$ diam, Schleicher \& Schuell GmbH, Dassel, Germany) were sprayed with the tested plant enhancers $48 \mathrm{~h}$ before the experiment. Each paper was rolled in a small glass cup $(50 \mathrm{ml})$ and was put in the olfactometer bottles. As a control, filter paper was sprayed with the same amount of distilled water. The remaining three vessels of the six-arm-olfactometer remained empty.

Odor Trapping Volatiles emitted by the various odor sources were trapped on Super Q adsorbent filters $(25 \mathrm{mg}, 80$ 100 mesh; Alltech Associates, Deerfield, IL, USA)(Turlings et al., 2004) for $3 \mathrm{~h}$ during the bioassays. Before use, traps were washed with $3 \mathrm{ml}$ dichloromethane. In all experiments, a filter was attached to the horizontal port at the top of each odor source vessel. Purified air entered the bottles at a rate of $1.1 \mathrm{~L} / \mathrm{min}$, and air carrying the volatiles was pulled through each trap at a rate of $0.7 \mathrm{~L} / \mathrm{min}$ (Analytical Research System, Gainesville, FL, USA). Traps were extracted with $150 \mu \mathrm{l}$ dichloromethane (Super solvent;
Merck, Dietikon, Switzerland), and 200 ng of n-octane and n-nonyl acetate (Sigma, Buchs, Switzerland) in $10 \mu \mathrm{l}$ dichloromethane were added to each sample as internal standards (IS). Samples either were analyzed immediately or stored at $-80^{\circ} \mathrm{C}$ before analysis in small vials (Supelco, Amber Vial, $7 \mathrm{ml}$ with solid cap w/PTFE Liner).

Odor samples were analyzed using a gas chromatograph (Agilent 7890A) coupled to a mass spectrometer (Agilent $5975 \mathrm{C}$ VL MSD). After injection of $2 \mu \mathrm{l}$ of sample, the temperature was maintained at $40^{\circ} \mathrm{C}$ for $3.5 \mathrm{~min}$, and then increased to $100^{\circ} \mathrm{C}$ at $8^{\circ} \mathrm{C} / \mathrm{min}$, and subsequently to $200^{\circ} \mathrm{C}$ at $5^{\circ} \mathrm{C} / \mathrm{min}$, followed by a post-run of $5 \mathrm{~min}$ at $250^{\circ} \mathrm{C}$. Helium at constant flow $(0.9 \mathrm{ml} / \mathrm{min})$ was used as carrier gas. Volatiles were identified by comparing their mass spectra with those of the NIST05 library and by comparing their retention times with those of previous analyses (HoballahFritzsche et al., 2002; D'Alessandro and Turlings, 2005; D'Alessandro et al., 2009). The total emission for each compound was calculated as the sum of the amounts for all compounds released during the collection period $(3 \mathrm{~h})$.

Effect of Plant Enhancers on Herbivore Leaf Consumption To assess whether the studied plant enhancers affected herbivore growth, experiments were carried out under light benches in a climatized laboratory $\left(25 \pm 2^{\circ} \mathrm{C}, 40 \pm 10 \%\right.$ r.h., 16:8 hL: D and $\left.148 \mu \mathrm{mol} / \mathrm{m}^{2} \mathrm{~s} 1\right)$. First, the plants were treated with plant enhancers as above. Controls were sprayed with water only. After $48 \mathrm{~h}$, individual plants were infested with single second instar $S$. littoralis larvae, and PET-tubes $(30 \mathrm{~cm}$ high, conal shape, top-diam: $8 \mathrm{~cm}$ ) were placed over the plants and attached to the pots with Parafilm $(N=24)$ (see Erb et al., 2011). The tubes were open at the top to ensure air-circulation. Larvae were weighed before each assay to determine their initial weight, and larval weight gain was recorded every second day. After $8 \mathrm{~d}$ of feeding, the herbivores were removed, and the plants were scored for survival. Plants that had been completely eaten were considered dead.

Quantification of Gene Expression To test whether the studied plant enhancers have an effect on the expression of plant defense marker genes, maize plants with three fully developed leaves were treated with BTH or Laminarin as described above. In a second experiment, the plants additionally were induced by mechanical damage and regurgitant application as described. In total, six plants were used for each treatment and analyzed as individual biological replicates. Total RNA was extracted using Quiagen RNA-Easy extraction kits following the manufacturer's instructions. To remove contaminant genomic DNA, all samples were treated with AmbionDNAse following the manufacturer's protocol. cDNA then was synthesized using Invitrogen Super-Script III reverse transcriptase according to the manufacturer's instructions. Quantitative 
reverse transcriptase real time polymerase chain reactions (qPCR) were carried out using gene-specific primers. The qPCR mix consisted of $5 \mathrm{ul}$ Quantace Sensimix containing Sybr Green I, 3.4ul $\mathrm{H}_{2} 0,100 \mathrm{nmol}$ of each primer $\left(2 \mathrm{x} 0.3 \mathrm{ul} \mathrm{H}_{2} 0\right)$, and $1 \mathrm{ul}$ of cDNA sample. Q-PCR was carried out using 45 cycles with the following temperature curve: $10 \mathrm{~s} 95^{\circ} \mathrm{C}, 20 \mathrm{~s}$ $60^{\circ}, 15 \mathrm{~s} 72^{\circ}$. The final melt curve was obtained by ramping from 68 to $98^{\circ} \mathrm{C}$ in $1^{\circ} \mathrm{C}$ steps every $5 \mathrm{~s}$. To determine primer efficiencies and optimal quantification thresholds, a dilution series of a cDNA mix consisting of 4ul solution from every sample was created. Six 10-fold dilution steps were carried out and the standard curve was included into every q-PCR run. The final obtained $\mathrm{Ct}$ values (using the automated threshold determination feature of the Rotor-Gene 6000 software) were corrected for the housekeeping gene GapC (Frey et al., 2000) and normalized to control levels to obtain average fold changes of treated plants.

Statistical Analyses The functional relationship between parasitoid responses and the different volatile sources offered in the six-arm olfactometer was examined with a generalized linear model as described earlier (Turlings et al., 2004). The model was fitted by maximum quasilikelihood estimation in the software package $\mathrm{R}(R$ : A language and Environment for Statistical Computing, Version 2.9.0, Zurich, Switzerland, 2009, http://www.R-project.org), and its adequacy was assessed through likelihood ratio statistics and examination of residuals (Turlings et al., 2004). Volatile emission, larval performance, and gene expression data were analyzed by one-way ANOVAs and Tukey's post-hoc comparison of treatment means when the data were normally distributed and the variances were homogeneous. If assumptions for normally distributed data with homogeneous variances could not be fulfilled, we used the non-parametric Kruskal-Wallis or Mann-Whitney Rank Sum tests and then compared treatment effects using Dunn's test. These analyses were performed with SigmPlot 12 (SPSS Inc, Chicago, IL, USA).

\section{Results}

\section{Wasp Behavior}

Spodoptera littoralis Damaged Maize Plants In a first test, we investigated whether Laminarin and BTH alter the attractiveness of S. littoralis infested plants to parasitoids. Generally, all tested naïve female wasps were more attracted to the odor of $S$. littoralis attacked plants treated with Laminarin and BTH than to $S$. littoralis attacked plants that were not treated. Cotesia marginiventris showed a strong preference for both BTH and Laminarin treated plants $\left(F_{3,176}=29.64 ; P<0.001\right)$ (Fig. 1a $\left.)_{1}\right)$, while Campoletis sonorensis $\left(F_{3,176}=14.67 ; P<0.001\right)$ and
Microplitis rufiventris $\left(F_{3,176}=50.04 ; P<0.001\right)$ preferred the odor of Laminarin treated plants, but did not distinguish between untreated and BTH treated plants (Fig. 1 $a_{2}, 1 . a_{3}$ ). In all cases, the wasps chose more often for the arms carrying the odor of plants than control arms.

Mechanically Damaged Maize Plants In a next experiment, we investigated the effect of Laminarin and BTH on the attractiveness of artificially induced maize plants. Again, all tested species were most strongly attracted to induced plants that were treated with Laminarin (Fig. 1b). Cotesia marginiventris females showed a strong preference for Laminarin and BTH treated plants $\left(F_{3,176}=30.17 ; P<0.001\right)$ (Fig. $\left.1 b_{1}\right)$, while $C$. sonorensis $\left(F_{3,176}=19.67 ; P<0.001\right)$ and $M$. rufiventris were more attracted only by Laminarin treated plants $\left(F_{3,176}=51.46 ; P<0.001\right)$ (Fig. $\left.1 b_{2}, 1 . b_{3}\right)$.

Undamaged Maize Plants To test if Laminarin and BTH also increase the attractiveness of undamaged plants, we treated healthy seedlings with the plant enhancers. Cotesia marginiventris (Fig. $1 \mathrm{c}_{1}$ ) did not distinguish among BTH treated, Laminarin treated and untreated control plants, whereas treatment with Laminarin increased the attractiveness of undamaged plants to $C$. sonorensis (Fig. $1 \mathrm{c}_{2}$ ). Surprisingly, $M$. rufiventris showed a preference for untreated control plants compared to BTH or Laminarin treated plants $\left(F_{3,176}=19.67\right.$; $P<0.001$ ) (Fig. $1 \mathrm{c}_{3}$ ), implying that the elicitors themselves may have been somewhat repellent to this parasitoid. In all cases, odors coming from vessels containing plants were more attractive than odors from empty control bottles (Fig. 1c).

BTH and Laminarin When we tested BTH and Laminarin on filter paper in the olfactometer, the wasps were not attracted to the compounds themselves (Fig. $1 d_{1,2,3}$ ). The majority of the wasps remained in the central chamber of the olfactometer, and the few wasps that did make a choice showed no significant preference for any of the arms. ( $C$. marginiventris: $F_{3},{ }_{176}=1.25, P=0.292 ; C$. sonorensis: $F_{3}$, ${ }_{176}=2.42, P=0.067 ;$ M. rufiventris: $F_{3,176}=2.00, P=0.115$ ).

\section{Volatile Emissions}

Spodoptera littoralis Damaged Maize Plants Generally, the total amount of volatiles emitted by $S$. littoralis attacked plants treated with Laminarin was significantly less compared to BTH or untreated plants $\left(F_{2,35}=3.89 ; P<0.001\right)$, and trans-ocimene was the only compound that was released in significantly larger amounts when maize plants were treated with BTH $\left(H_{2,35}=8.56 ; P=0.014\right)$.

Indole emission was strongly suppressed by Laminarin and BTH $\left(H_{2}, 32=7.25 ; P=0.027\right)$. Methyl anthranilate was significantly lower for Laminarin treated plants, but not for BTH treated plants $\left(H_{2,26}=7.17 ; P=0.028\right)$. Laminarin and 
Campoletisonorensis

(1)
(2)
Microplitis rufiventris

(3)

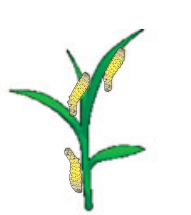

(A)

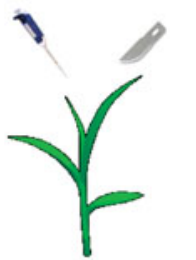

(B)

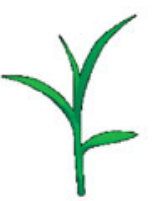

(C)

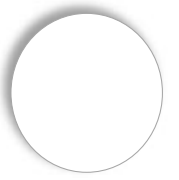

(D)
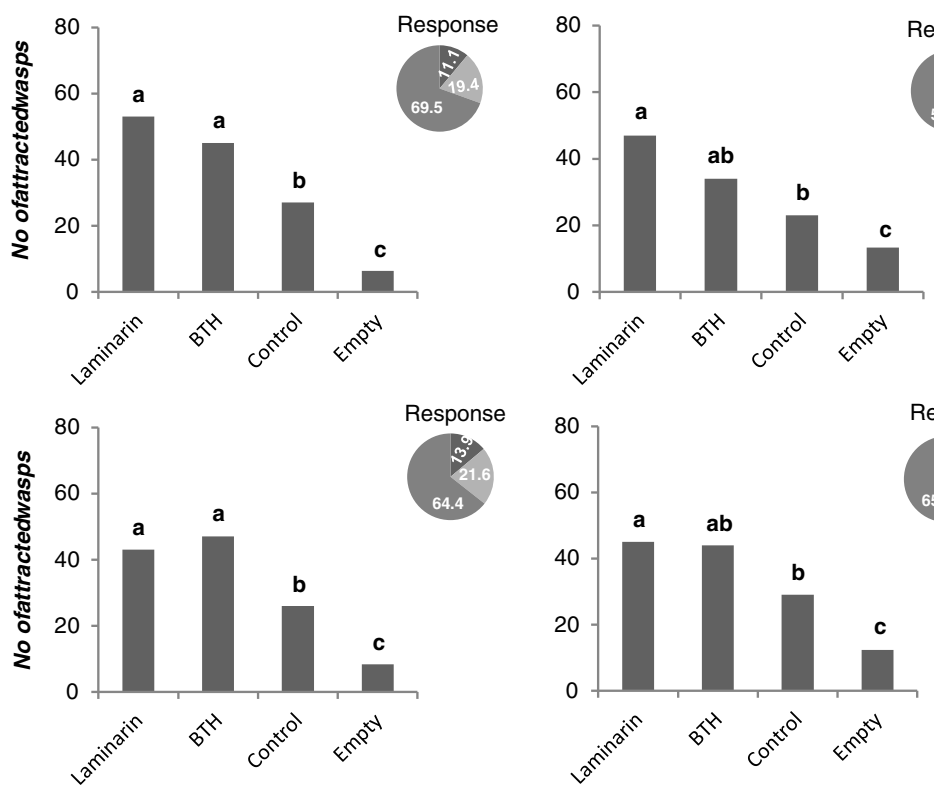

Response
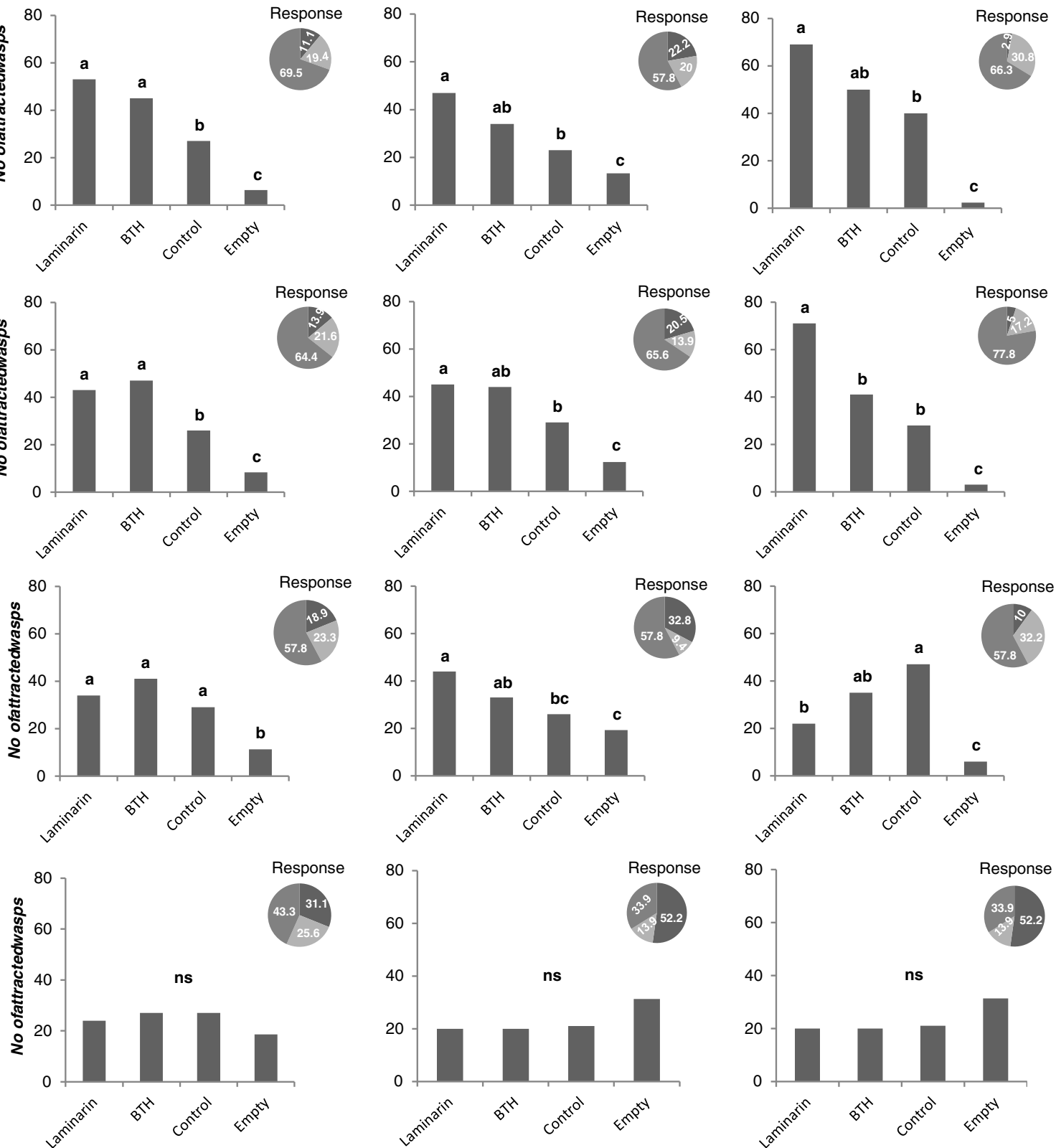

Fig. 1 Responses of naive female wasps tested in six-arm olfactometer. Values shown are number of attracted parasitoid to a particular odor. Wasps were allowed to choose between odors of Laminarin = Laminarin-sprayed maize plants, BTH $=$ BTHsprayed maize plants, Control $=$ Distilled water-sprayed maize plants, and Empty = Empty control vessel (mean value of three vessels). a Ten 2nd instars of Spodoptera littoralis were added to plants $24 \mathrm{~h}$ before the experiment. b Plants were mechanically damaged and treated with Spodoptera littoralis regurgitant. c

BTH application led to a decrease in $(E)$-beta-caryophyllene emissions $\left(F_{2,21}=3.54 ; P=0.047\right)$. Beta-Bergamotene and (E)-beta-farnesene were supressed by Laminarin, but not by BTH $\left(F_{2,34}=3.37, P=0.046 ; F_{2,25}=4.24, P=0.026\right.$ ) (Fig. 2 ).

Plants were undamaged and carefully inserted in the bottles. d Three filter papers (Rundfilter $185 \mathrm{~mm}$ diam) were sprayed with Laminarin, BTH, and distilled water. Pie charts indicate percentages of female wasps (dark gray $=$ females choose the empty bottles; light gray $=$ non-responding females; gray $=$ responding females). Thirty wasps were released per experimental day. This assaying was carried out for 6 successive experimental days. Different letters on the same bars indicate significant differences $(P<0.05)$

Mechanically Damaged Maize Plants Similarly to the experiment with $S$. littoralis, the total quantity of volatiles released by artificially induced, Laminarin-treated plants was reduced by $50 \%$ compared to control plants $\left(H_{2,32}=\right.$ 


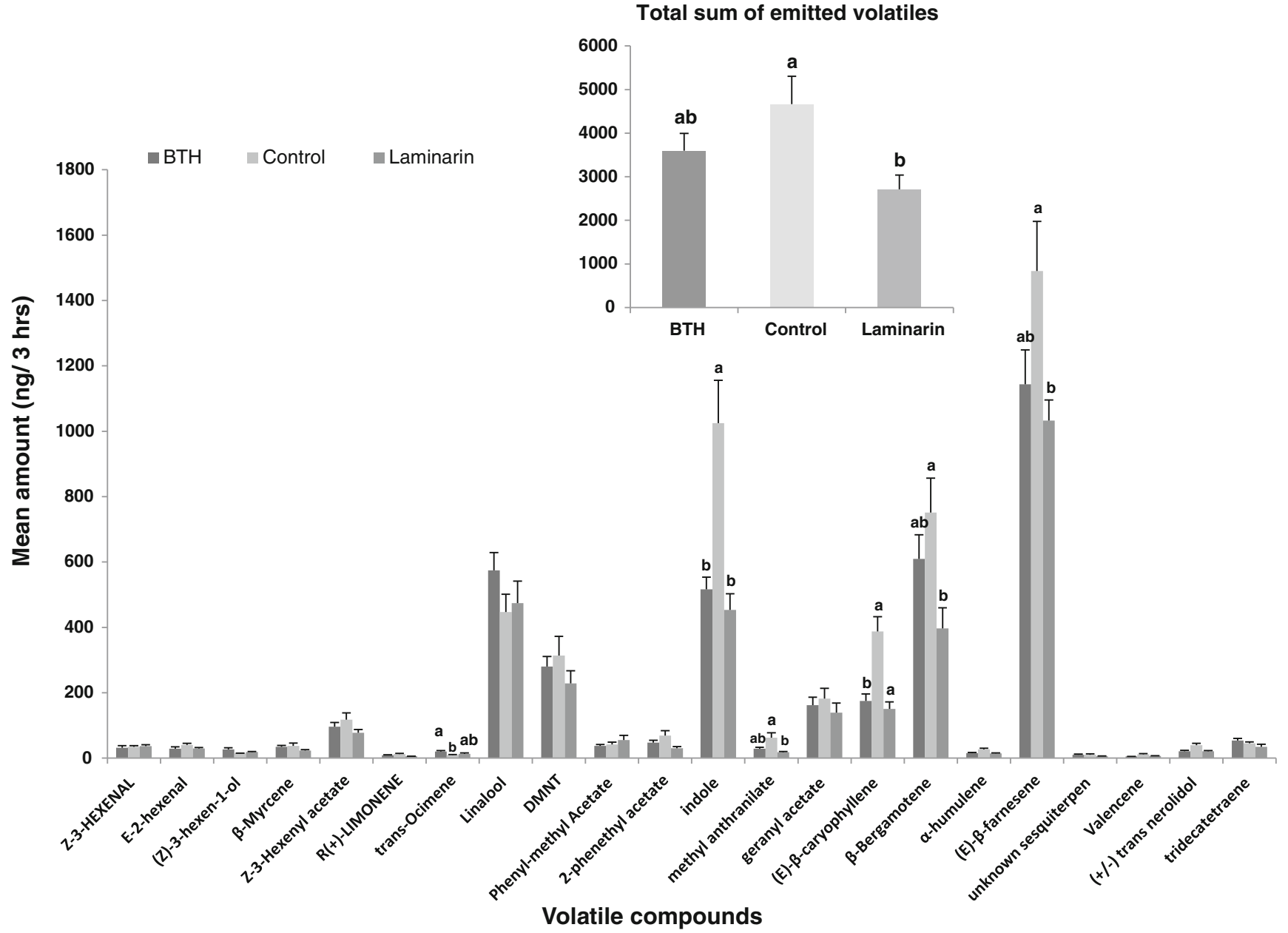

Fig. 2 Mean amount ( \pm SE) (ng) of induced volatiles emitted during $3 \mathrm{~h}$ by Spodoptera littoralis-damaged maize seedlings (11 d-old). Laminarin $=$ Laminarin-sprayed maize plants, $\mathrm{BTH}=\mathrm{BTH}$-sprayed maize plants, Control $=$ distilled water-sprayed maize plants. Different letters on the

9.34; $P=0.009$ ). Generally, the release of volatiles following induction with mechanical damage and herbivore regurgitant was 10 times lower than after S. littoralis attack (Fig. 3). Therefore, only the 12 most abundant individual volatiles could be quantified. Most quantified compounds showed the same trends as in the previous experiment, with a few exceptions: BTH treatment significantly attenuated the emission of $(Z)-3$-Hexenal acetate $\left(F_{2,19}=7.46 ; P=0.004\right)$, and $(E)$-beta-caryophyllene $\left(H_{2,32}=6.20 ; P=0.045\right)$. Also, linalool was significantly suppressed with Laminarin treatment $\left(F_{2,28}=3.95 ; P=0.031\right)$.

Larval Performance Overall, S. littoralis neonate larvae (2nd instar) survived equally well on Laminarin and BTH treated and untreated control plants (Fig. 4). During the first two days after treatment, larval growth was increased on BTH-treated plants $\left(F_{3,91}=3.19 ; P=0.027\right)$ (Fig. 5). This difference disappeared at later stages of development ( 4 days: $H_{3,83}=4.83, P=0.185$; 6 days: $H_{3,82}=0.42 ; P=0.937 ; 8$ days: $\left.F_{3,79}=0.69 ; P=0.559\right)$. same bars indicate significant differences $(P<0.05)$ in the amount of a specific compound ( $N=18$ per treatment). The compounds are ordered in accordance with their retention time in a gas chromatograph

Gene Expression Of the 11 defense markers genes that were tested for expression (Erb et al., 2009), two pathogenesis related genes, $Z m-P R 1$ and $Z m-P R 5$, were induced 3-fold by BTH and Laminarin (Fig. 6a). Zm-CysII, a herbivoreinduced cystatin homologue (Ton et al., 2007), was induced by BTH. Most marker genes were strongly induced by mechanical wounding and $S$. littoralis regurgitant application (Fig. 6b). Neither BTH nor Laminarin treatment changed this pattern: The only differences we observed was a slightly reduced induction of $Z m-P R l$ by Laminarin and a reduction of $\mathrm{Zm}-\mathrm{Igl}$, the maize indole synthase (Frey et al., 2004) following BTH treatment.

\section{Discussion}

One of the main responses of plants to herbivore-attack is the release of a specific blend of volatiles that can attract carnivorous natural enemies of herbivores (Turlings and Wäckers, 
Total sum of emitted volatiles

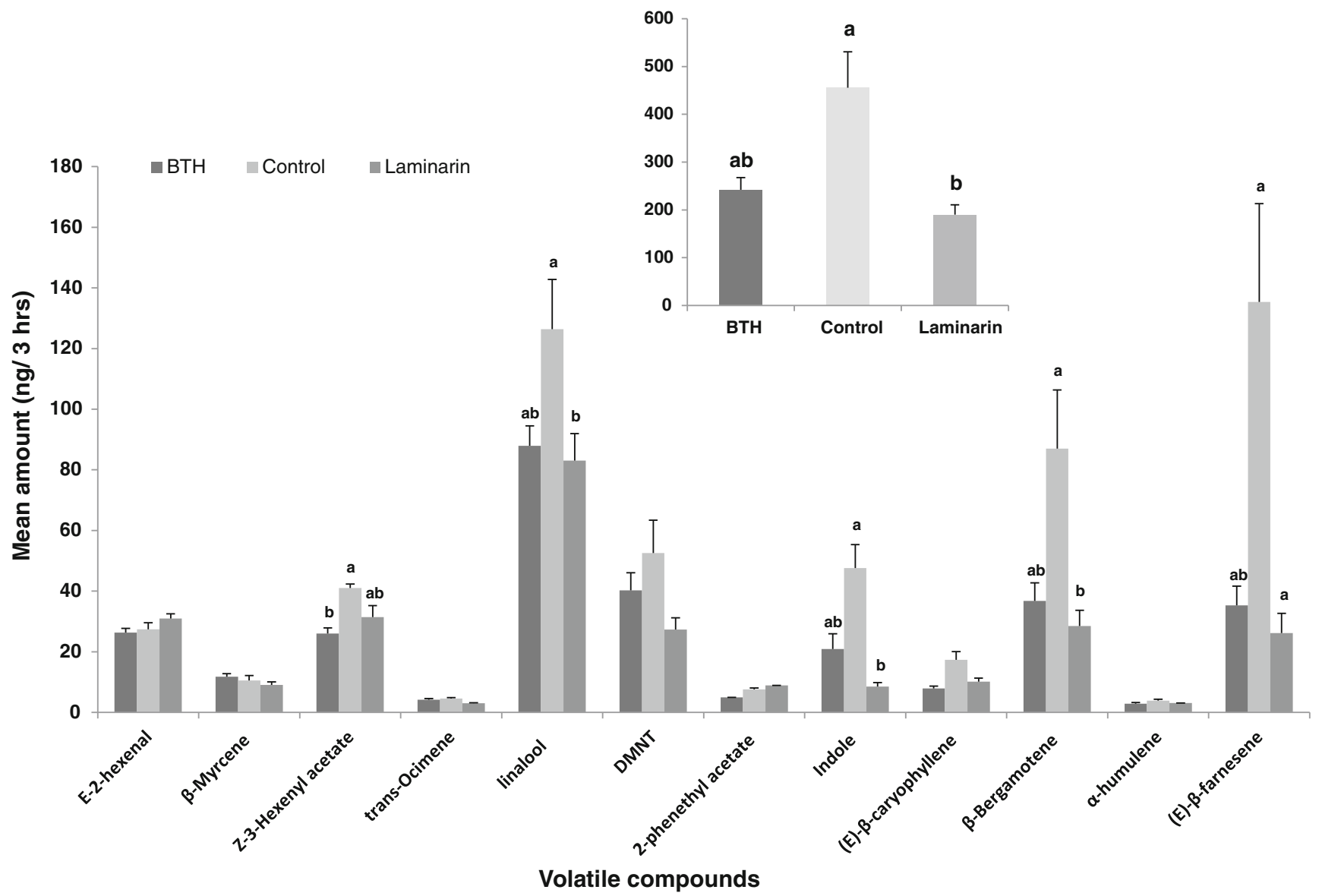

Fig. 3 Mean amount ( \pm SE) (ng) of induced volatiles emitted during $3 \mathrm{~h}$ by maize seedlings ( $11 \mathrm{~d}$-old) that were artificially damaged and treated with regurgitant of Spodoptera littoralis caterpillars. Laminarin = Laminarin-sprayed maize plants, BTH $=$ BTH-sprayed maize plants,
Control $=$ distilled water-sprayed maize plants. Different letters on the same colored bars indicate significant differences $(P<0.05)$ in the amount of a specific compound ( $N=18$ per treatment). The compounds are ordered in accordance with their retention time in a gas chromatograph

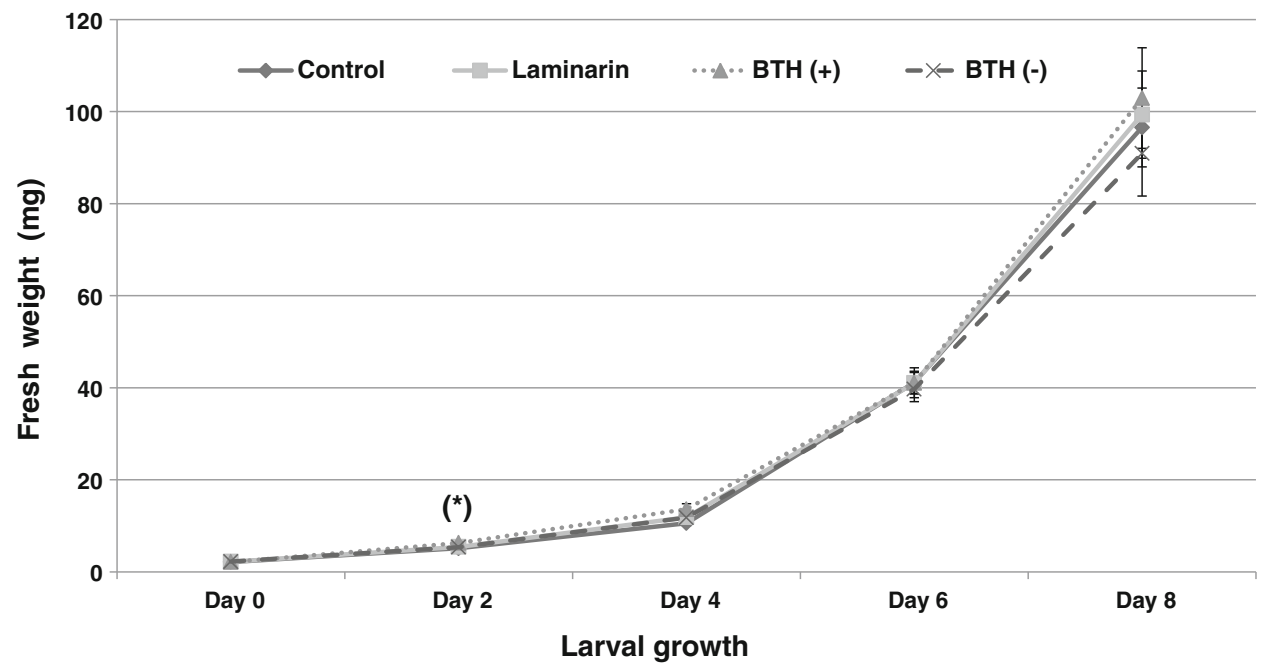

Fig. 4 Performance of Spodoptera littoralis larval stage on sprayed maize plants. Laminarin $=$ Laminarin-sprayed maize plants, BTH $(+)=$ BTH-sprayed maize plants, BTH $(-)=$ BTH product without its active ingredient-sprayed maize plants, $\mathrm{Control}=$ distilled water-sprayed maize plants. Each caterpillar fed on a single plant. Means \pm SE are given. Larval weighing was done every second day. No significant differences were found between treatments after the second weighing (Holm-Sidak method, $P<0.05)$. (*) There is a significant difference between treatments 
Fig. 5 Weight gain of

Spodoptera littoralis larvae fed on sprayed maize plants.

Laminarin $=$ Laminarin-sprayed maize plants, BTH $(+)=$ BTHsprayed maize plants, BTH (-) $=\mathrm{BTH}$ product without its active ingredient -sprayed maize plants, Control $=$ distilled water-sprayed maize plants. Each caterpillar fed on a single plant. Means $\pm \mathrm{SE}$ are given. A significant difference was found between treatments $\left(F_{3,91}=\right.$ 3.19, $P=0.027)($ Holm-Sidak method)
Weightgain1 (day2- day0)

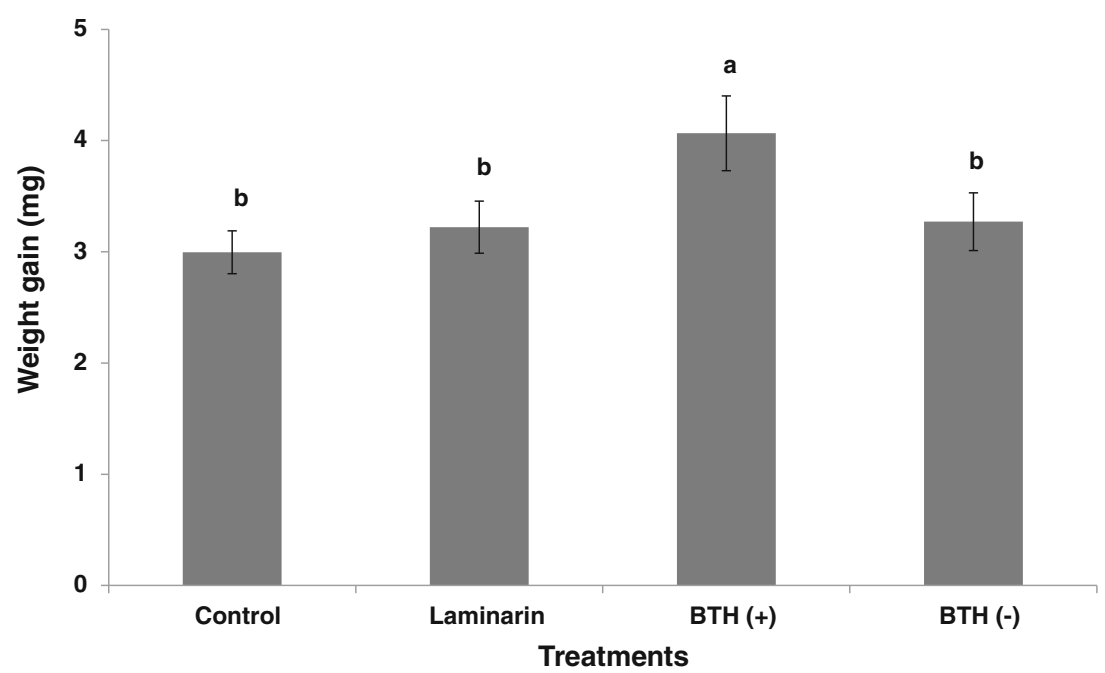

2004; Dicke and Baldwin, 2010). It is expected that proper manipulation of the release of such volatiles in crop plants may enhance the effectiveness of biological control agents
(Degenhardt et al., 2003; Turlings and Ton, 2006). Yet, in many cases, plant volatile blends are complex, and not all compounds in a mixture contribute equally to herbivore
Fig. 6 a Fold change $( \pm \mathrm{SE})$ of defense marker gene expression in plants treated with different elicitors relative to untreated control plants. Asterisks above bars refer to near significant trends $\left(P_{\text {PR-1 }}=0.051\right),\left(P_{\text {CysII }}=\right.$ $0.057)$. b Fold change $( \pm \mathrm{SE})$ of defense marker gene expression in artificially induced plants treated with different elicitors relative to uninduced, untreated control plants. Different letters denote significant differences between treatments $(P<0.05)$

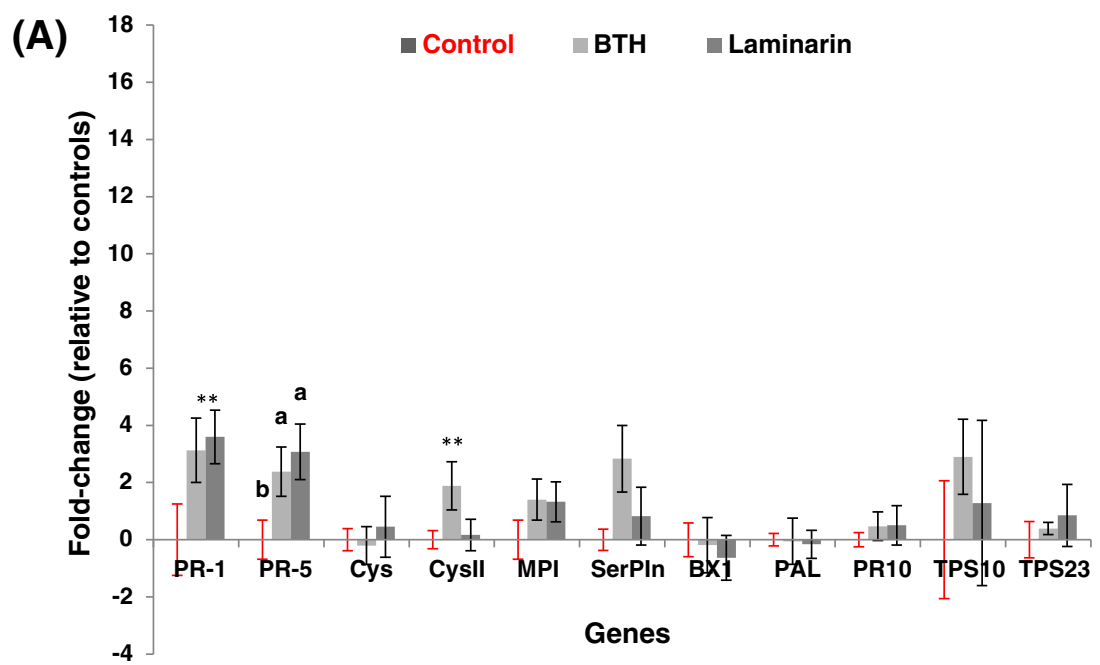

(B)

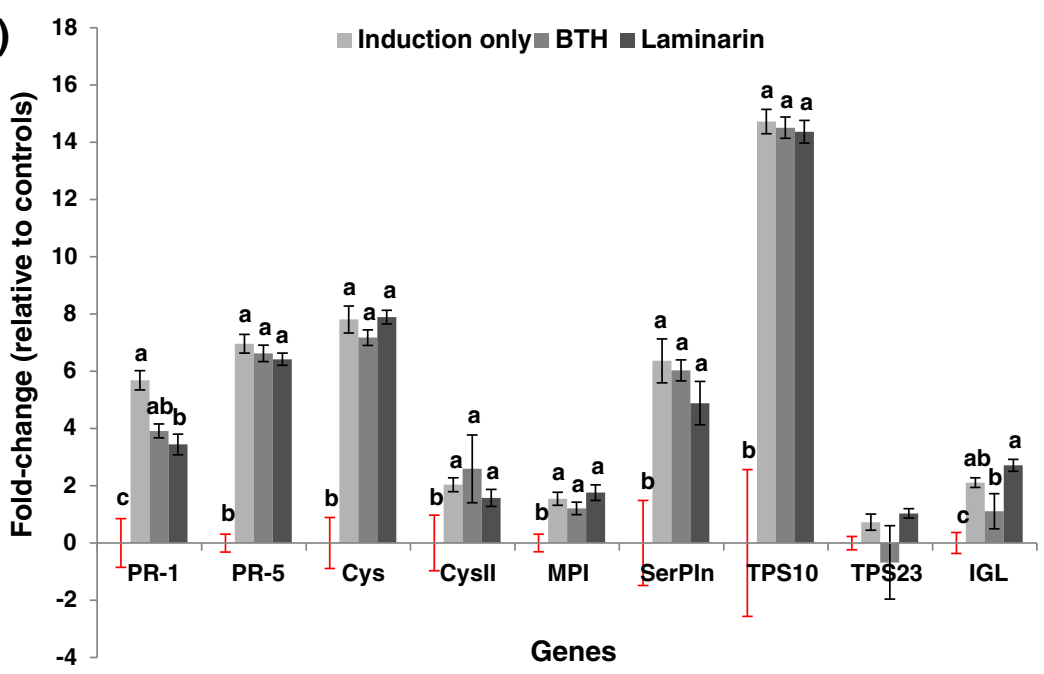


attraction, making targeted manipulation for pest control a difficult task.

The results show that pretreating maize seedlings with the plant enhancers Laminarin and BTH increases the attractiveness of herbivore-damaged plants to parasitic wasps. An earlier study (Rostás and Turlings, 2008) found that soildrenching with BTH enhances the attractiveness of maize plants to $M$. rufiventris, and our data expand upon these results, showing that foliar application has the same effect, also on two other, taxonomically very different wasps. Interestingly and contrary to general expectations, BTH and Laminarin suppressed the emission of several VOCs from $S$. littoralis infested and mechanically damaged plants. Detailed chemical analyses of all volatiles (including minor compounds) did not reveal the release of any additional volatiles that could have been triggered by or emitted from BTH or Laminarin. The compounds alone or applied to undamaged plants were not attractive, with the exception of Laminarin, which increased the attractiveness of undamaged plants to $C$. sonorensis.

We propose two hypotheses to explain why maize plants that emit less HIPVs are more attractive to the parasitoids. First, it is possible that the reduced volatiles may normally mask the attractive signals or even act as repellents. Several studies done on the same system indicate that neither the dominant sesquiterpenes (Schnee et al., 2006) nor aromatic compounds (D'Alessandro et al., 2006) are important for the innate attraction of the studied parasitoids (Rostás and Turlings, 2008). In fact, inhibiting the production of indole has been shown to enhance the attraction of $M$. rufiventris (D'Alessandro et al., 2006). Second, it is possible that BTH and Laminarin treatment enhance the production of yet unknown key attractants. Fractionation-guided bioassays and other earlier studies indeed indicate that the behaviorally active compounds emitted by herbivore-infested maize plants may not be detectable by conventional GC-MS methods (D'Alessandro et al., 2009), and we can, therefore, not exclude that the emissions of these compounds were enhanced by the plant strengtheners. Overall, the presented data suggest that for parasitoid attraction in maize, less may be more. In other words, plants that produce fewer of the common HIPVs are better able at attracting a wide range of parasitoids. Clearly, further studies are required to unravel the mechanisms behind this counter-intuitive phenomenon.

From a mechanistic perspective, the suppressant effect of BTH and Laminarin on the induction of volatile organic compounds may be related to their proposed mode of action. BTH acts downstream of SA (Friedrich et al., 1996) and elicits accumulation of SA responsive genes and pathogenesisrelated proteins (PRPs). Our gene expression measurements confirm the accumulation of PR transcripts following BTH treatment. As there is negative cross talk between the SA and the JA pathway (Thaler et al., 2002b; Ozawa et al., 2000; Heil and Bostock, 2002), and HIPVs in maize are thought to depend on JA (Schmelz et al., 2001), it is possible that BTH acts as a suppressor of the herbivore-induced JA response, resulting in a lower production of volatiles. Further evidence hinting at a suppression of defenses comes from our S. littoralis performance experiment, which showed that caterpillars grow slightly better on BTH-treated plants. Surprisingly, however, we found no reduced induction of JA-responsive genes following BTH treatment, suggesting that BTH affects a different regulatory mode. As sesquiterpene emissions were reduced, but the corresponding terpene synthases TPS10 and TPS23 were expressed normally, it is possible that BTH changed the available precursor pool or the photosynthetic activity of the plant rather than acting on the genes themselves. In general, it can be expected that the effect of BTH will also depend on the dose of application (Choh et al., 2004). Here, we used the plant strengthener at a relatively low concentration of $0.15 \mathrm{~g} / \mathrm{L}$, which corresponds to the recommended dose of the manufacturer for field application.

Similarly to BTH, many studies indicate that oligo- and polysaccharides can act as elicitors of pathogen defense (Kobayashi et al., 1993). Yet, the mechanism by which polysaccharides act in the plant is not fully understood (Mercier et al., 2001). In grapevine, Laminarin elicits a variety of defense reactions, including alkalinization of the extracellular medium, an oxidative burst, activation of two mitogen-activated protein kinases, expression of 10 defenserelated genes with different kinetics and intensities, increases in chitinase and 1,3-glucanase activities, and the production of two phytoalexins (Aziz et al., 2003). Obara et al. (2002) also found that chitosan oligomers can trigger the emission of linalool, MeSA, and $\beta$-caryophyllene in rice plants (Oryza sativa). One study found that after chemical sulfation, Laminarin becomes an inducer of the salicylic acid (SA) signaling pathway in tobacco and Arabidopsis thaliana. In tobacco, Laminarin also was shown to induce the expression of ethylene-dependent PR proteins, whereas PS3 ( $\beta$-1, 3-glucan sulfate) triggers the expression of ethylene- and SA-dependent PR proteins (Ménard et al., 2004; Trouvelot et al., 2008). In our experiments, Laminarin had effects similar to BTH, not only in terms of volatile emission and parasitoid attraction, but also regarding the slight induction of PR genes. This suggests that in maize, Laminarin triggers a similar response as BTH. It would be interesting to assess whether the two plant strengtheners act redundantly or in synergy when applied together.

A recent field study conducted in maize plots in subtropical Mexico found only minor effects of BTH application on herbivore and parasitoid recruitment (von Mérey et al., 2012). The severe biotic and abiotic conditions under which these field assays were conducted may have masked the effects of BTH treatment. However, it can be safely 
concluded from this field study and the current lab study that treating maize with BTH or Laminarin is compatible with biological control of lepidopteran pests, and their application may, under certain conditions, even improve the control mediated by parasitic wasps.

In the field, pathogens and herbivores often attack an individual plant simultaneously or in sequence (Rostás et al., 2003; Stout et al., 2006). Therefore, protecting crops against diseases by using Laminarin and BTH could lead to a potential conflict, as both elicitors activate defenses against pathogens, but may weaken plant resistance against certain herbivores (Heil and Bostock, 2002; Stout et al., 2002; Taylor et al., 2004; Bostock, 2005; Beckers and Spoel, 2006). Our data suggest, however, that these potential negative effects of plant strengtheners may be outweighed by their positive effect on multitrophic interactions: BTH and Laminarin treated plants are likely to become more attractive to a wide variety of parasitoids after herbivore attack, and furthermore, through the suppression of the dominating plant volatiles, treated plants may be less apparent to herbivores that use HIPVs for host location (Halitschke et al., 2008). The results are encouraging news for those that aim to improve the plants immune system by applying plant strengtheners. Further fieldwork will have to reveal the full potential of this approach.

Acknowledgements We thank the members of the Laboratory of Fundamental and Applied Research in Chemical Ecology (FARCE), University of Neuchâtel for continuous support and stimulating discussions on behavioral and chemical aspects. In particular, we thank Matthias Held, Georg von Mérey and Marco D'Alessandro for their statistical advice and helpful comments and discussion during the early stages of conception and development of the manuscript. We are grateful to Yves Borcard, Gwlades Doyen, and students of the University of Neuchâtel for parasitoid rearing, and Syngenta ${ }^{\mathrm{TM}}$ (Stein, Switzerland) for the weekly shipments of $S$. littoralis eggs. Also, we thank Neil Villard for his help with the PCR analyses. The work was funded in part by the Swiss National Center of Competence in Research Plant Survival and by grant 3100A0-122132/1 from the Swiss National Science foundation. I.S. expresses his thanks to the Egyptian Ministry of Higher Education, Public Sector of Scholarships and Scientific Missions, which financially supported his research. Further, the Egyptian Academy of Scientific Research is gratefully acknowledged.

\section{References}

Alborn, H.T., Turlings, T.C.J., Jones, T.H., Stenhagen, G., LOUGHRIN, J.H., and TUMLINSON, J.H. 1997. An elicitor of plant volatiles from beet armyworm oral secretion. Science 276: 945949.

Arimura, G., Kost, C., and Boland, W. 2005. Herbivore-induced, indirect plant defences. Biochim. Biophys. Acta 1734:91-111.

Arimura, G., Matsui, K., and TAKABAYASHI, J. 2009. Chemical and molecular ecology of herbivore-induced plant volatiles: proximate factors and their ultimate functions. Plant Cell Physiol. 50:911923.

Aziz, A., Poinssot, B., Daire, X., Adrian, M., Bezier, A., LAMBert, B., Joubert, J. M., and Pugin, A. 2003. Laminarin elicits defense responses in grapevine and induces protection against Botrytis cinerea and Plasmopara viticola. Mol. Plant-Microbe In. 16:11181128.

Beckers, G. J. M. and Spoel, S. H. 2006. Fine-tuning plant defence signalling: salicylate versus jasmonate. Plant Biol. 8:1-10.

Bostock, R. M. 2005. Signal crosstalk and induced resistance: Straddling the line between cost and benefit. Annu. Rev. Phytopathol. 43:1-36.

CHOH, Y., OZAWA, R., and TAKABAYASHI, J. 2004. EFFECTS OF EXOGENOUS JASMONIC ACID AND BENZO $(1,2,3)$ THIADIAZOLE-7CARBOTHIOIC ACID S-METHYL ESTER (BTH), A FUNCTIONAL ANALOGUE OF SALICYLIC ACID, ON THE EGG PRODUCTION OF A HERBIVOROUS MITE TETRANYCHUS URTICAE (ACARI: TETRANYCHIDAE). APPL. ENTOMOL. AND ZOOL. 39:313-316.

D'AlesSANDRO, M., HELD, M., TRIPONEZ, Y., and TuRLINGS, T. C. J. 2006. The role of indole and other shikimic acid derived volatile organic compounds in the attraction of two parasitic waps. $J$. Chem. Ecol 32:2733-2748.

D'ALESSANDRO, M., BRUNNER, V., VON MÉREY, G., and TURLINGS, T. C. J. 2009. Strong attraction of the parasitoid Cotesia marginiventris towards minor volatile compounds of maize. J. Chem. Ecol. 35:999-1008.

D'Alessandro, M. and TURLINGS, T. C. J. 2005. In Situ modification of herbivore-induced plant odors: A novel approach to study the attractiveness of volatile organic compounds to parasitic wasps. Chem. Senses 30:739-753.

Degenhardt, J., Gershenzon, J., BALdwin, I. T., and Kessler, A. 2003. Attracting friends to feast on foes: engineering terpene emission to make crop plants more attractive to herbivore enemies. Curr. Opin. Biotech. 14:169-176.

Degenhardt, J., Hiltpold, I., Köllner, T. G., Frey, M., Gierl, A., Gershenzon, J., Hibbard, B. E., Ellersieck, M. R., and TuRLINGS, T. C. J. 2009. Restoring a maize root signal that attracts insect-killing nematodes to control a major pest. P. Natl. Acad. Sci. USA 106:13213-13218.

DiCKE, M. 2009. Behavioral and community ecology of plants that cry for help. Plant, Cell Environ. 32:654-665.

DickE, M. and BALDWIN, I. T. 2010. The evolutionary context for herbivore-induced plant volatiles: beyond the 'cry for help'. Trends Plant Sci. 15:163-175.

Dicke, M., Gols, R., Ludeking, D., and Posthumus, M. A. 1999. Jasmonic acid and herbivory differentially induce carnivoreattracting plant volatiles in lima bean plants. J. Chem. Ecol. 25:1907-1922.

Erb, M., Flors, V., Karlen, D., De Lange, E., Planchamp, C., D'Alessandro, M., TURLINGS, T. C. J., and TON, J. 2009. Signal signature of aboveground-induced resistance upon belowground herbivory in maize. The Plant J. 59:292-302.

ERB, M., Foresti, N., and TURLINGS, T. C. J. 2010. A tritrophic signal that attracts parasitoids to host-damaged plants withstands disruption by non-host herbivores. BMC Plant Biol. 10:247.

ERB, M., Balmer, D., De LANGe, E. S., Von MÉrey, G., PlanchamP, C., ROBERT, C. A., RÖDER, G., SOBHY, I., ZWAHLEN, C., MAUCH-MANI, B., and TuRLINGS, T. C. J. 2011. Synergies and trade-offs between insect and pathogen resistance in maize leaves and roots. Plant Cell Environ 34:1088-1103.

Frey, M., Stettner, C., Pare, P. W., Schmelz, E. A., Tumlinson, J. H., and GIERL, A. 2000. An herbivore elicitor activates the gene for indole emission in maize. P. Natl. Acad. Sci. USA 97:1480114806.

Frey, M., Spiteller, D., Boland, W., and Gierl, A. 2004. Transcriptional activation of igl, the gene for indole formation in Zea mays: A structure-activity study with elicitor-active n-acyl glutamines from insects. Phytochemistry 65:1047-1055.

Friedrich, L., Lawton, K., Ruess, W., Masner, P., Specker, N., Rella, M. G., Meier, B., Dincher, S., Staub, T., Uknes, S., 
Metraux, J. P., Kessmann, H., and Ryals, J. 1996. A benzothiadiazole derivative induces systemic acquired resistance in tobacco. The Plant $J$ 10:61-70.

Gorlach, J., Volrath, S., Knauf-Beiter, G., Hengy, G., Beckhove, U., Kogel, K. H., Oostendorp, M., Staub, T., Ward, E., Kessmann, H., and Ryals, J. 1996. Benzothiadiazole, a novel class of inducers of systemic acquired resistance, activates gene expression and disease resistance in wheat. The Plant Cell 8:629-643.

Halitschke, R., Stenberg, J. A., Kessler, D., Kessler, A., and BALDWIN, I. T. 2008. Shared signals - "alarm calls" from plants increase apparency to herbivores and their enemies in nature. Ecol. Lett. 11:24-34.

HEIL, M. 2004. Induction of two indirect defences benefits Lima bean (Phaseolus lunatus, Fabaceae) in nature. J. Ecol. 92:527-536.

HeIL, M. and Bostock, R. M. 2002. Induced systemic resistance (ISR) against pathogens in the context of induced plant defences. Ann. Bot. 89:503-512.

Hoballah, M. E. and Turlings, T. C. J. 2005. The role of fresh versus old leaf damage in the attraction of parasitic wasps to herbivore-induced maize volatiles. J. Chem. Ecol. 31:2003-2018.

Hoballah-Fritzsche, M., TAMÒ, C., and TurlingS, T. C. J. 2002. Differential attractiveness of induced odors emitted by eight maize varieties for the parasitoid Cotesia marginiventris: is quality or quantity important? J. Chem. Ecol. 28:951-968.

Inbar, M., DoOstdar, H., SONODA, R. M., Leibee, G. L., and MAYER, R. T. 1998. Elicitors of plant defensive systems reduce insect densities and disease incidents. J. Chem. Ecol. 24:135-149.

KapPers, I. F., Aharoni, A., VAN Herpen, T., LuCKerhoff, L. L. P., DicKe, M., and BOUWMEESTER, H. J. 2005. Genetic engineering of terpenoid metabolism attracts bodyguards to Arabidopsis. Science 309:2070-2072.

Klarzynski, O., Plesse, B., Joubert, J. M., Yvin, J. C., KopP, M., KloAREG, B., and Fritig, B. 2000. Linear beta-1,3glucans are elicitors of defense responses in tobacco. Plant Physiol. 124:1027-1038.

KobaYASHI, A., TAI, A., KANZAKI, H., and KAWAZU, K. 1993. Elicitoractive oligosaccharides from algal laminaran stimulate the production of antifungal compounds in alfalfa. Z. Naturforsch. 48:575-579.

MÉnard, R., Alban, S., De Ruffray, P., Jamois, F., Franz, G., Fritig, B., Yvin, J. C., and KufFMANN, S. 2004. $\beta-1,3$ glucan sulfate, but not $\beta-1,3$ glucan, induces the salicylic acid signaling pathway in tobacco and Arabidopsis. Plant Cell 16:3020-3032.

Mercier, L., Lafitte, C., Borderies, G., Briand, X., EsquerréTUGAYÉ, M., AND FouRNIER, J. 2001. The algal polysaccharide carrageenans can act as an elicitor of plant defence. New Phytol. 149:43-51.

Morris, S. W., Vernooij, B., Titatarn, S., Starrett, M., Thomas, S., Wiltse, C. C., Frederiksen, R. A., Bhandhufalck, A., HULBERT, S., and UKNES, S. 1998. Induced resistance responses in maize. Mol. Plant Microbe In. 11:643-658.

OBARA, N., HASEgaWA, M., and KodAma, O. 2002. Induced volatiles in elicitor-treated and rice blast fungus-inoculated rice leaves. Biosci. Biotech. Bioch. 66:2549-2559.

Ozawa, R., Arimura, G., Takabayashi, J., Shimoda, T., and NisHIOKA, T. 2000. Involvement of jasmonate- and salicylaterelated signaling pathways for the production of specific herbivoreinduced volatiles in plants. Plant and Cell Physiol. 41:391-398.

RASMANN, S. and TurlingS, T. C. J. 2007. Simultaneous feeding by aboveground and belowground herbivores attenuates plantmediated attraction of their respective natural enemies. Ecol. Lett. 10:926-936.

Read, S. M., Currie, G., and Bacic, A. 1996. Analysis of the structural heterogeneity of Laminarin by electrospray-ionisationmass spectrometry. Carbohyd. Res. 281:187-201.
Rostás, M. and Turlings, T. C. J. 2008. Induction of systemic acquired resistance in Zea mays also enhances the plant's attractiveness to parasitoids. Biol. Control 46:178-186.

Rostás, M., Simon, M., and HiLKer, M. 2003. Ecological crosseffects of induced plant responses towards herbivores and phytopathogenic fungi. Basic Appl. Ecol. 4:43-62.

Schmelz, E. A., Alborn, H. T., and Tumlinson, J. H. 2001. The influence of intact-plant and excised-leaf bioassay designs no volicitin and jasmonic acid induced sesquiterpene volatile release in Zea mays. Planta 214:171-179.

Schnee, C., Köllner, T. G., Held, M., Turlings, T. C. J., GerSHENZON, J., and DEgenhardT, J. 2006. A maize terpene synthase contributes to a volatile defense signal that attracts natural enemies of maize herbivores. P. Natl. Acad. Sci. USA 103:11291134.

Smith, J. L., De Moraes, C. M., and Mescher, M. C. 2009. Jasmonate- and salicylate-mediated plant defense responses to insect herbivores, pathogens and parasitic plants. Pest Manag. Sci. 65:497-503.

Stout, M., Zehnder, G. W., and BAur, M. E. 2002. Potential for the use of elicitors of plant resistance in arthropod management programs. Arch. Insect Biochem. Physiol. 51:222-235.

Stout, M. J., Thaler, J. S., and Thomma, B. P. H. J. 2006. Plantmediated interactions between pathogenic microorganisms and herbivorous arthropods. Annu. Rev. Entomol. 51:663-689.

TAlly, A., OOSTENDORP, M., LAWTON, K., Staub, T., and Bassi, B., 1999. Commercial development of elicitors of induced resistance to pathogens, pp. 357-369, in: A.A. Agrawal, S., Tuzun, and E., Bent, (eds.). Induced Plant Defences against Pathogens and Herbivores: Biochem. Ecol. Agri., APS Press, St Paul, MN, USA.

TAMÒ, C., RicARD, I., Held, M., DAVISON, A. C., and Turlings, T. C. J. 2006. A comparison of naïve and conditioned responses of three generalist endoparasitoids of lepidopteran larvae to hostinduced plant odors. Ani. Biol. 56:205-220.

TAYlor, J. E., Hatcher, P. E., and PAul, N. D. 2004. Crosstalk between plant responses to pathogens and herbivores: a view from the outside in. J. Exp. Bot. 55:159-168.

THALER, J. S. 1999. Jasmonate-inducible plant defences cause increased parasitism of herbivores. Nature 399:686-688.

Thaler, J. S., Farag, M. A., Pare, P. W., and Dicke, M. 2002a. Jasmonate-deficient plants have reduced direct and indirect defences against herbivores. Ecol. Lett. 5:764-774.

Thaler, J. S., Karban, R., Ullman, D. E., Boege, K., and BosTOCK, R. M. 2002b. Cross-talk between jasmonate and salicylate plant defense pathways: effects on several plant parasites. Oecologia 131:227-235.

Ton, J., D'alessandro, M., Jourdie, V., Jakab, G., Karlen, D., Held, M., MaUch-Mani, B., and Turlings, T. C. J. 2007. Priming by airborne signals boosts direct and indirect resistance in maize. Plant $J$ 49:16-26.

Trouvelot, S., Varnier, L., Allègre, M., Mercier, L., Baillieul, F., Arnould, C., Gianinazzi-Pearson, V., Klarzynski, O., Joubert, J. M., Pugin, A., and DAire, X. 2008. A $\beta-1,3$ glucan sulfate induces resistance in grapevine against Plasmopara viticola through priming of defense responses, including HR-like cell death. Mol. Plant Microbe In. 21:232-243.

TurLings, T. C. J. and Ton, J. 2006. Exploiting scents of distress: the prospect of manipulating herbivore-induced plant odors to enhance the control of agricultural pests. Curr. Opin. Plant Biol. 9:421-427.

TURLINGS, T.C.J., and WÄCKERS, F.L. 2004. Recruitment of predators and parasitoids by herbivore-damaged plants, pp. $21-75$, in R. T. Cardé and J. Millar (eds.). Advances in Insect Chemical Ecology, Cambridge University Press.

TurlingS, T. C. J., Tumlinson, J. H., and Lewis, W. J. 1990. Exploitation of herbivore-induced plant odors by host-seeking parasitic wasps. Science 250:1251-1253. 
Turlings, T. C. J., Lengwiler, U. B., Bernasconi, M. L., and WeCHSLER, D. 1998. Timing of induced volatile emissions in maize seedlings. Planta 207:146-152.

Turlings, T. C. J., Davison, A., and TAMÒ, C. 2004. A six-arm olfactometer permitting simultaneous observation of insect attraction and odor trapping. Physiolog. Entomol. 29:45-55.

Vallad, G. E. and Goodman, R. M. 2004. Systemic acquired resistance and induced systemic resistance in conventional agriculture. Crop Sci. 44:1920-1934.
Von Mérey, G. E., Veyrat, N., De Lange, E., Degen, T., Mahuku, G., VAldeZ, R. L., Turlings, T. C. J., and D'Alessandro, M. 2012. Minor effects of two elicitors of insect and pathogen resistance on volatile emissions and parasitism of Spodoptera frugiperda in Mexican maize fields. Biol Control. 60:715.

VON RAD, U., Mueller, M. J., and Durner, J. 2005. Evaluation of natural and synthetic stimulants of plant immunity by microarray technology. New Phytol 165:191-202. 